\title{
THE PERFORMANCE OF THE FAMILY HEALTH STRATEGY NURSE IN THE CARE OF CLIENTS IN PSYCHIC SUFFERING
}

\author{
A ATUAÇÃO DOS ENFERMEIROS DA ESTRATÉGIA DE SAÚDE DA FAMÍLIA EM \\ CLIENTES EM SOFRIMENTO PSÍQUICO
}

\section{Patricia Iolanda Coelho ALVES ${ }^{1}$; Lúcia Aparecida FERREIRA ${ }^{2}$; Ricardo Jader CARDOSO ${ }^{3}$; Fernanda Bonato ZUFFI ${ }^{4}$; Leiner Resende RODRIGUES ${ }^{5}$; Marina Pereira REZENDE ${ }^{6}$; Guilherme Silva MENDONÇA ${ }^{7}$; Emerson Piantino DIAS ${ }^{8}$}

1. Nurse graduated from the undergraduate course in Nursing of the Federal University of Triângulo Mineiro, Uberaba, MG, Brasil; 2. Ph.D in Nursing, Professor at the Federal University of Triângulo Mineiro, Uberaba, MG, Brazil; 3. Ph.D in Nursing, Professor at the Federal University of Triângulo Mineiro, Uberaba, MG, Brazil; 4. Master Professor in Nursing, Professor at the Federal University of Triângulo Mineiro, Uberaba, MG, Brazil; 5. Ph.D. in Nursing, Professor at the Federal University of Triângulo Mineiro; 6. Ph.D. in Nursing; Professor at the Federal University of Triângulo Mineiro; 7. Pedagogue, Nurse, Specialist Distance Education, Master's student in the Postgraduate Program in Health Sciences at the Federal University of Uberlândia, Uberlândia, MG, Brazil.

guilhermesilva@famed.ufu.br; 8. Master in Health Promotion from the University of Franca, Professor at the Federal University of Uberlândia, Uberlândia, MG, Brazil.

\begin{abstract}
Aim: To verify the performance of the nurses, in addition to identifying difficulties and facilities in assisting the client in psychic suffering. Design: Descriptive study, of exploratory and qualitative approach. Participants and context: The sampling consisted of 26 nurses of Primary Care - Family Health Strategy from Uberaba - MG, in 2012. Main measurements: It was used a semi-structured questionnaire, with guiding questions. Data were analyzed using content analysis. Results: Six categories emerged: nurse assignments, access to medication; difficulty of access to the center of specialty, professional qualification, teamwork, and lack of facilities. Conclusion: ESF nurses' actions are routing, guidance and monitoring. Lack of training, access to medications and specialty centers were the difficulties encountered by them. And teamwork was considered a facilitator.
\end{abstract}

PALAVRAS-CHAVE: Psychic suffering. Mental health. Family health strategy.

\section{INTRODUCTION}

Mental disorders remain an extremely complex field, full of theoretical concerns that challenge science in assistance to clients in psychic suffering (COSTA; ANJOS; ZAHER, 2007).

Population is walking slowly toward the psychiatric post reform transformation, especially as regards the vision formed on the client in psychic suffering, which has as difficulties the insufficiency of information and the complications in the system modification (MONTEIRO; ET ALL.; 2012).

A person in psychic suffering is considered an individual with rights and duties, and mental health care must be in accordance with his/her potential and participation in the treatment (MIELKE; OLCHOWSKY, 2010).

Mental health is the ability to live overcoming losses and pains imposed by life, being the human being able to demonstrate and control feelings according to each situation and persons (GOUVEIA; ZACCARA; COSTA; LIMA; GADELHA, 2009).

The Ordinance $\mathrm{N}^{\circ}$. 224/92 from the Ministry of Health regulates the reduction of hospitalizations with the implementation of a new model of extramural psychiatric care as the Psycosocial Attention Centers (CAPS), Therapeutic Residential Services and Day-Hospitals (GOUVEIA; ZACCARA; COSTA; LIMA; GADELHA, 2009). The Family Health Program (PSF), later the Family Health Strategy (ESF) began in Brazil in 1991 with the purpose of reorganizing the health care, making professionals humanize the service and develop prevention and health recovery actions fully and continuously (SOUSA, 2007).

The family health Strategy (FHS) develops preventive actions and early detection of mental illness because it is the closest to the community. It acts with the de-institutionalization reasoned on the principles of the Unified Health System (SUS) and the Psychiatric Reform, which recommend working in networks, based on territorial and transversal actions with other specific policies (REINALDO, 2008), beyond embracement, dialogue, attachment and listening, for greater understanding of the client in psychic suffering, to meet their needs (MIELKE; OLSCHOWSKY, 2011). Is currently expected that nurses use the assumptions of the care system, scientifically characterizing the performance of nursing as a profession, with careful ruled in nursing diagnosis. The nursing process properly used in the 
mental patient approach helps in decision-making, and subsidies for interventions in the psychoemotional problems (BETEGHELLI; TOLEDO; CREPSCHI; DURAN; 2005).

Psychiatric nursing is based on actions that seek to improve the quality of life conditions of the client and his family for help in controlling the outbreak of the disease, making it stable and assist in social integration, cooperate on adherence and adaptation to treatment, since the client in psychic suffering, in its majority, has the autonomy reduced (ALMEIDA FILHO; MORAES; PERES; 2009).

In primary care/ESF the nurse even in the face of difficulties and/or facilities, has the possibility to early detect the distress of his client once his performance on this site allows him to establish ties with the community and get to know its reality.

Providing nursing care in primary care services is not an easy task, individuals are diversified and the assistance to the client in psychic suffering requires the professional to have sensitivity, holistic look and expertise.

The number of researches with this theme is scarce, besides the professional deficiency with training and specialization in Psychiatry and mental health in our country.

The aim of this study was to check the performance of the nurses in the care of this client, identify difficulties and facilities with strategies that can extend the knowledge, expand information on provision of care according to the needs of each client.

\section{MATERIAL AND METHODS}

Study of exploratory, descriptive and qualitative approach. All the nurses who worked in the family health Strategy (ESF) from the urban area of the city of Uberaba-MG participated in the study, except professionals who were on vacation and health license, making up a sampling of 26 nurses. As inclusion criteria to participate in the research is being nurse ESF. The exclusion criterion is not being a nurse ESF. Research began after obtained written consent Health Municipal Secretary of the city and evaluation and approval by the Ethics and Research Committee (CEP) of Universidade Federal do Triângulo Mineiro (UFTM), opinion $\mathrm{N}^{\circ}$. 1999, in accordance with the Resolution 196/96 of the National Health Council, which deals with research involving humans.

Data collection was based on two parts. The first part consisted of: initials, age, sex, marital status, number of children, religion, ESF of the city currently working and professional experience. The second part consisted of an instrument with guiding questions. 1. Have you ever assisted any client in Psychic suffering? 2. What is your performance in the assistance of a client in psychic suffering? 3 . What are the facilities and difficulties encountered while attending a client in psychic suffering? It was research during the period from December 2011 to January 2012. The interview was performed by the researcher and occurred in the FHS in time scheduled by the nurse, in a separate room. The majority-16 did not allow recording the interview, responding in writing in the presence of the researcher. Respondents signed an informed consent prior to the start of the interview, maintaining the secrecy and anonymity by using letters followed by the number of the interview, E1, E2.

With the data obtained in general the researcher must engage in a thorough reading of the material extracted from the collection, identify the units of meaning, categorize them according to themes, make inferences and analyze these findings according to their theoretical framework. Minayo (2004), the operationalization of the thematic analysis covers three stages: 1) Pre-analysis are determined at this stage, the registration units - key words or phrases, the context units, indentations, as categorization and general theoretical concepts that guide the analysis, taking into account the central and objective research question; 2) Exploration Material: is the transformation of the initial data, aiming to understand the text from your core sense. The procedure is the text of the cut in registration units and performs the classification and aggregation of data; 3) Treatment of Results Obtained: is the interpretation of data, as categorized by correlating them with the theoretical framework underlying the research.

\section{RESULTS AND DISCUSSION}

On sociodemographic characteristics of the respondents, it was found that from the $26(100 \%)$ nurses interviewed in ESF, 24 (92.3\%) were female and two (7.7\%) were male. Only two (97.7\%) concluded post-graduation Lato Sensu. The age ranged from 26 to 49 years. Related to the time of performance in ESF, 13 (50\%), had an average of five years. All of the nurses interviewed (100\%) replied they have treated clients in psychic suffering in the performance of their daily activities.

With the data obtained in the survey analysis and categorization were made based on directives proposed by Minayo (2004), which covers three stages: pre-analysis; exploration of the 
material, and processing of the results obtained. From the analyses drawn from the interviews, six categories have emerged as a result of the grouping, namely: 1. Assignments of nurses; 2 . Access to the medication; 3. Difficulty of access to the specialty Centre; 4. training; 5. teamwork; 6. facilities absence.

\section{Nurse tasks}

In this category, it was highlighted that one of the roles of the nurse is to guide the client in psychic suffering and his family with regard to medications or even reference to other specialties through reference, counter reference, and follow up this client through the Family Health Strategy.

Orientation and Follow up. (E01)

First approach, second embracement, third referral, follow up. (E03)

It is more about referral, because we do not have support, there is no medication here, we have only one general practitioner, and then we end up having to guide them to the specialty. (E07)

Orientation, referral and follow up. (E11)

The role of the nurse is to direct user and family regarding signs/symptoms, ways to prevent aggravations. Guide the user to the specialized sector. (E16)

When working with the client in psychic suffering the nurse must break up with his own prejudices. These were imposed by society since the early days of "madness", sort the client in psychic suffering as aggressive, and associate him to the asylums. For the nurse to develop his function with professionalism and commitment, he needs to acquire skill and detachment (RIBEIRO; ET ALL.; 2010). Nursing care to the client in psychic suffering must be integral, see the client as a whole (ALENCAR; FERNANDES; 2010). It is a fundamental role of the nurse to develop resolutive health actions, listen to the client, therapeutic groups and home visits. However, such actions were not reported in the study carried out in Fortaleza-CE (CAVALCANTE; ET ALL.; 2011). Another study showed that the nurse, when faced with clients in psychic suffering makes the referral his main tool, and directs them to other professionals specialized in mental health (AMARANTE; ET. ALL.; 2011)

\section{Access to medication}

The unavailability of specific drugs in the ESFs to the clients in psychic suffering was signed out as one of the greatest difficulties of the respondents when assisting this client. We can observe it through the following lines:
[...] there are no medication in the basic attention [...]. (E03)

\section{[...]. Lack of medications and psychotropics in times of crisis. [...]. (E05)}

[...]There is no medication, no support, adherence, doctor, so, it is not possible to do much [...]. (E07)

The lack of medication supply to clients in psychic suffering in ESF is a difficult point cited in the study conducted in four ESFs in the city of Salvador-BA in 2007 (NUNES; JUCÁ; VALENTIN; 2007), corroborating with this research.

\section{Difficulties in accessing the specialties center}

In this category, the nurses point out as difficult the lack of integration between the ESF and the CAPS, as well as the absence of specialized professionals as the psychologist and psychiatrist. It was evidenced in reports:

[...] Despite being defined the front doors, the accesses are hampered for the specialties in CAPS, psychiatry and psychology [...]. (E03)

Complex approach, also dependent on other professionals and attendances [...] difficulty for scheduling psychologist/psychiatrist $[\ldots]$. (E14)

[...] Our greatest difficulty is the lack of specialists in this area (psychiatrist). Our demand on psychiatric clients is very large. (E18)

Health networks have sturdy and complex relationships, what makes difficult the integration and cooperation between these services. It is essential that the ESF and the mental health reference centers interact among themselves in order to encourage a broad and humanized care to the client in psychic suffering, promoting his best referral (SCHNEIDER, 2009).

The inclusion of mental health actions in the ESFs is occurring slowly and gradually, due to the absence or insufficiency of services geared to mental health, the disarticulation of the customer care network to clients in psychic suffering, the lack of communication of the services and mental health knowledge in the territory from the ESF as a strategy in psychosocial rehabilitation (MIELKE; OLCHOWSKY, 2010).

\section{Professional qualification}

The lack of training in the area of Psychiatry/mental health is one of the difficulties 
The performance of the family...

faced by professionals when assisting the clients in psychic suffering, as shown in the following lines:

The first difficulty is not to have training opportunity for a better development of the work, because when client is presenting a psychotic manifestation we do not know the better ways of performing the assistance. (E04)

Further clarification/training in the area. (E11)

\section{[...] lack of professional qualification. (E14)}

Preparation, qualification, handling, referral, reference, difficulty in requesting vacancy, vacancy provision (E16)

In a study conducted in three ESF units in the city of Natal-RN, one of the goals was to identify the level of training of nurses from ESF when assisting the client in psychic suffering (RIBEIRO; ET. ALL.; 2010). Lack of professional training and insufficient practical theoretical basis in mental health are difficult factors in the care of psychic suffering client (OLIVEIRA; CORREA; VIEIRA; 2011).

\section{Work team}

Work teamwas considered as a facilitator point when assisting the client in psychic suffering. Workteam; humanization in health care[...]. (E05)

\section{Talking/dialogue/patience/prior experiencel multiprofissional team support(E16)}

I believe our greatest facility is the support the general practitioner from PSF offers us [...] we rely on the support of the psychologist from NASF (E18).

Support in the health units by other professionals in service [...]. (E14)

The team acts as the primary tool of intervention and production of customer care to the client in psychic suffering (YASUI; COSTA ROSA; 2008). When talking about teamwork, interdisciplinarity and multidisciplinarity should be primary requirements, with the purpose of promoting exchange of experiences favoring the psychosocial rehabilitation of the client (SCHNEIDER, 2009).

\section{Absence of facilities}

ALVES, P. I. C. et al.

Regarding to the care of clients in psychic suffering the nurses interviewed referred absence of facilities. This study reveals the following lines:

I see no facilities. (E13)

There are more difficulties, I can't find facilities. (E17)

Facility? No, I can't see facility. [...]. (E20)

None. (E10)

In the daily life of the ESFs, the team faces difficult situations in mental health, due to the bond and closeness acquired with families. Actions relating to mental health in the family health teams must follow the precept of care networks, territorial base and transversal actions, paying attention to specific policies that meet the creation of attachments and reception to the client (MINISTÉRIO DA SAÚDE, 2003).

It was noticed in this study that the actions taken by the nurses of ESF were guidance, orientation and monitoring, while attending a patient in psychic suffering. It was still noticed that one of the difficulties found is the lack of preparation to live and act in situations in which the client is in your threshold of "madness". The cultural roots, which stigmatizes the psychic client, are still strong. It was pointed out as a positive and facilitator point the work of the multiprofessional team, so that client care and monitoring can be carried out in its totality.

ESF and Mental Health walk slowly.Managers must implement actions of public health policies that may offer the client in psychic suffering worthy, integral and continuous care, giving opportunity to those health professionals to attend training courses in mental health, physical and financial resources for the development of strategies aimed at the quality of life, respect and dignity to these clients.

This study made it possible to show that there is no resolution in the basic attention, since the professional nurse prioritizes the referral of the client to other spheres of service, exempting himself from responsibility of completeness. It is necessary to review the concepts of psychic suffering, because most actors interviewed associates the pathology in the acute phase. 
RESUMO: Objetivo: Verificar a atuação dos enfermeiros, além de identificar as dificuldades e facilidades ao atender o cliente em sofrimento psíquico. Estudo: descritivo, abordagem exploratória e qualitativa. Participantes e contexto: A amostragem foi de 26 enfermeiros da Estratégia Saúde da Família de Uberaba - MG, em 2012. Método: Utilizou-se questionário semi estruturado e com perguntas norteadoras. Os dados foram analisados utilizando análise de conteúdo. Resultados: Surgiram seis categorias: Atribuições do Enfermeiro; Acesso à medicação; Dificuldade de acesso ao centro de especialidade; Capacitação Profissional; Trabalho em Equipe; e Ausência de facilidades. A assistência de enfermagem ao cliente em sofrimento psíquico deve ser integral. É papel fundamental do enfermeiro desenvolver ações resolutivas de saúde. Conclusão: As ações dos enfermeiros de ESF são: encaminhamento, orientação e acompanhamento. A falta de capacitação, acesso aos centros de especialidades e medicamentos, foram as dificuldades encontradas por eles. E o trabalho em equipe um ponto facilitador.

PALAVRAS-CHAVES: Sofrimento psíquico. Saúde mental. Estratégia saúde da família.

\section{REFERENCES}

ALENCAR, A. K. B.; FERNANDES, T. G. Assistência de Enfermagem aos indivíduos com transtornos mentais: uma revisão de literatura por Metassíntese. Saúde Transform. Soc., Florianópolis, v. 1, n. 1, p. 148$153,2010$.

ALMEIDA FILHO, A. J.; MORAES, A. E. C.; PERES, M. A. A. Atuação do enfermeiro nos centros de atenção psicossocial: Implicações históricas da enfermagem psiquiátrica. Rev. Rene, v. 10, n. 2, p. 158-165, abr./jun. 2009.

AMARANTE, A. L.; LEPRE, A. S.; GOMES, J. L. D.; PEREIRA, A. V.; DUTRA, V. F. D. As estratégias dos enfermeiros para o cuidado em saúde mental no programa saúde da família. Texto Contexto-Enferm., Florianópolis, v. 20, n. 1, p. 85-93, Jan-Mar. 2011.

BETEGHELli, P.; TOLEDO, V. P.; CREPSCHI, J. L. B.; DURAN, E. C. M. Sistematização da assistência de enfermagem em um ambulatório de saúde mental. Rev. Eletrônica Enferm., v.7, n. 3, p.334-343, 2005.

BRASIL, Ministério da Saúde. Secretaria de Atenção à Saúde. Saúde Mental e Atenção Básica - Vínculo e Diálogo Necessários. Circular Conjunta nº 01/03, de 13/11/03.

CAVAlCANTE, C. M.; PINTO, D. M.; CARVAlHO, A. Z. T.; JORGE, M. S. B.; FREITAS, C. H. A. Desafios do Cuidado em Saúde Mental na Estratégia Saúde da Família. Rev. Bras. Promoç. Saúde, Fortaleza, v. 24, n. 2, p. 102-108, abr/jun. 2011.

COSTA, J. R. E.; ANJOS, M. F.; ZAHER, V. L. Para compreender a doença mental numa perspectiva de bioética. Bioethikos, v.1, n.2, p.103-110, jul/dez. 2007.

GOUVEIA, E. M. L.; ZACCARA, A. A. L.; COSTA, T. F.; LIMA, L. F.; GADELHA, V. N. Atuação do enfermeiro na assistência aos portadores de esquizofrenia: uma perspectiva bioética. Anais do II Encontro Nacional de Bioética e Biodireito e do III Encontro de Comitês de Ética em Pesquisa da Paraíba. João Pessoa: Ed. Universitária: UFPB. 2009. 627 p..

SOUSA, M.E.; MATIAS, G.N.; GOMES, K.F.A.; PARENTE, A.C.M. Atenção em Saúde Mental. Secretaria de Estado de Saúde de Minas Gerais. 2ist ed. Belo Horizonte; 2007.

MIELKE, F. B.; OLCHOWSKY, A. Saúde mental na Estratégia Saúde da Família: avaliação de apoio matricial. Rev. Bras. Enferm. Brasília, v. 63, n. 6, p. 900-7, 2010.

MIELKE, F. B.; OLSCHOWSKY, A. Ações de saúde mental na estratégia saúde da família e as tecnologias em saúde. Esc. Anna Nery, v. 15, n. 4, p. 762-768, 2011. http://dx.doi.org/10.1590/S1414-81452011000400015 
MINAYO, M. C. S. O desafio do conhecimento: pesquisa qualitativa em saúde. 7. ed. São Paulo: Hucitec/Rio de Janeiro: Abrasco, 2004. 269 p..

MONTEIRO, A. R. M.; TEIXEIRA, L. A.; SILVA, R. S. M.; RABELO, K. P. S.; TAVARES, S. F. V.; TÁVORA, R. C. O. Sofrimento psíquico em crianças e adolescentes - a busca pelo tratamento. Esc. Anna Nery, v. 16, n. 3, p. 523-529, 2012. http://dx.doi.org/10.1590/S1414-81452012000300014

NUNES, M.; JUCÁ, V. J.; VALENTIM, C. P. B. Ações de Saúde Mental no Programa Saúde da Família: confluências e dissonâncias das práticas com os princípios das reformas psiquiátrica e sanitária. Cad. Saúde Pública, Rio de Janeiro, v. 23, n. 10, p. 2375-2384, out. 2007.

OLIVEIRA, C. R. S.; CORREA, L. C. R.; VEIRA, A. L. Atenção ao portador de transtorno psíquico: a visão dos enfermeiros em unidades de saúde da família. Ensaios e Ciência: Ciências Biológicas, Agrárias e da Saúde, v. 15, n. 1, p. 121-139, 2011.

REINALDO, A. M. S. Saúde Mental na Atenção Básica como Processo Histórico de Evolução da Psiquiatria Comunitária. Esc. Anna Nery, v. 12, n. 1, p. 173-78, 2008. http://dx.doi.org/10.1590/S141481452008000100027

RIBEIRO, L. M.; MEDEIROS, S. M.; ALBUQUERQUE, J. S.; FERNANDES, S. M. B. A. Saúde mental e enfermagem na estratégia saúde da família: como estão atuando os enfermeiros?. Rev. Esc. Enferm., USP., v. 44, n. 2, p. 376-82, 2010. http://dx.doi.org/10.1590/S0080-62342010000200019

SCHNEIDER, A. R. S. A rede de atenção em saúde mental: a importância da interação entre a atenção primária e os serviços de saúde mental. Rev. Ciênc. Saúde, Porto Alegre, v. 2, n. 2, p. 78-84, jul/dez. 2009.

YASUI, S.; COSTA-ROSA A. A. Estratégia Atenção Psicossocial: desafio na prática dos novos dispositivos de Saúde Mental. Saúde em Debate, Rio de Janeiro, v. 32, p, 27-37, jan/dez. 2008. 